\title{
Structural analysis of types of Muslim religious consciousness
}

\author{
Axmed Abdurazakov', Olga Garnaya ${ }^{2,}{ }^{1}$, Michael Lebedev², and Emzari Yunusov ${ }^{2}$ \\ ${ }^{1}$ Federal State Institution of Additional Professional Education Interregional Training Center of \\ Federal Penitentiary Service of Russia for Moscow Region, Novye Doma settlement, Elektrostal, \\ Moscow Region, 142470, Russian Federation \\ ${ }^{2}$ Federal State Institution Research Institute of Federal Penitentiary Service of Russia, Narvskaya str., \\ 15 a, building 1, Moscow, 125130, Russian Federation
}

\begin{abstract}
A separate theoretical and legal study should be devoted to essential features of legal consciousness of Muslims, which will be based on the study of perception of positive law through the prism of Islamic religious and legal doctrine. It is advisable to start the basis of this study with definition of its main structural element - the types of Muslim legal consciousness. Consideration of this issue from the standpoint of natural law will expand the traditional boundaries of theory of modern legal consciousness, open up additional applied and scientific horizons and, using the example of Islam, allow us to consider peculiarities of religious influence on legal consciousness of various categories of citizens. Knowledge of foundations of Muslim law, procedure for formation of moral and social religious attitudes, interpretation of religious canons and dogmas contribute to a better understanding of many processes taking place within Russian Muslim community and can form the basis of mechanism for formation of moral legal consciousness, which must be opposed, in its turn, to radical and criminalized forms of religious consciousness.
\end{abstract}

\section{Introduction}

The methodology of specificity of legal deformations inherent in the modern Russian community is also largely conditioned by specificity of legal perception. Some mechanisms of positivist methodology reject the need to study religious and, in particular, Muslim legal consciousness, not noticing the obvious relationship between religiosity and legal thinking. In the face of existing challenges to the modern world, such a situation in domestic jurisprudence can no longer persist. A critical rethinking of a number of theoretical concepts contributes to the study of issues of determining characteristics of legal consciousness as the potential for formation of a civil society.

Dialectics of modern legal science takes an ever deeper coverage of law, allowing us to understand its deep, fundamental features, consider the issues of place and role of legal consciousness, study the resource potential of objective and subjective factors in the

\footnotetext{
*Corresponding author: olgaser545@mail.ru
} 
formation of legal consciousness, explore socio-cultural sources that form legal consciousness of modern society, and identify its objective sources through the study of whole variety of social types of legal consciousness.

\section{Methods}

An extensive scientific literature is devoted to the study of issues of legal consciousness, but most often the works were concentrated on the essence of legal consciousness of various social categories of society without differentiating subjects on the basis of religious belief.

Until now, there are no monographic studies in legal science in which the main attention would be paid to the issues of influence of Muslim legal ideology on formation of legal consciousness.

The issues of formation of Islamic law, its sources and features are analyzed in detail in the works of foreign authors such as R. David, A. Masse, R. Charles, D. Surdel, J. Surdel, M. Hodgson, A. Kh. Zarrinkub, L. V. Kh. Van den Berg and others. Soviet and Russian researchers of Muslim law, whose works were mainly used in writing this material, are S. Boronbekov, G. M. Kerimov, L. I. Klimovich, M.K.Sigalov, L.R.Syukiyainen, M.S. Khaidarova, M. B. Piotrovsky, B. A. Khamidov. The list is not exhaustive, but there are the works of these authors that form the general part of this study, becoming its theoretical basis.

Due to the specifics of subject of research, the main method is dialectical, since it implies a systematic approach to the phenomena under study, their consideration in development, taking into account specific historical realities. A systematic approach is of particular importance within the framework of this issue, since the subject of study is the formation of legal consciousness in the context of interaction of religion and law as forming moments of an integral social consciousness. In this work, along with these methods, a sociocultural approach is also used, which presupposes the interconnection of social, religious, cultural and dogmatic layers of life of society.

The fulfilling of formulated tasks to achieve the set goal is implemented on the basis of a systematic approach. In the process of work, dialectical method of scientific knowledge was used, from the standpoint of which phenomena and objects were considered comprehensively, in motion, development, interconnection and interaction with other phenomena and the environment.

General scientific (analysis, analogy, deduction, induction, synthesis, systemic and structural, functional, etc.) and specific scientific (formal legal, comparative jurisprudence, philological, etc.) methods were based on the dialectical method. Particular attention in the framework of methodology is paid to the activity, instrumental and functional approaches to the subject of research.

The comparative historical method has great heuristic potential for clarifying the essence of Islamic law. With its help, by comparison, the main types of Muslim legal consciousness are identified, knowledge of various historical stages of development of Muslim law is achieved in its inextricable connection with legal consciousness of Muslim society. To implement the tasks outlined, socio-psychological, ethnological, historical and other methods of researching materialist dialectics are used. All phenomena of social life have been investigated in their unity and the struggle of opposites, true knowledge was acquired by ascending from the abstract to the concrete. Theoretical basis of the study was the legacy of domestic and foreign historical and legal science, as well as religious sources of Muslim law. 


\section{Results}

Considering Muslim legal system only in a normative way does not provide a correct understanding of components of religiosity that underlie it. It is necessary to apply a broad approach from the standpoint of positivism, natural law, which implies not only legal norms, but also legal consciousness with its inherent sensual, unconscious, irrational perception. An example confirming the position stated above make the interviews conducted in the course of study with persons serving sentences in the Republic of Dagestan. During the conversations, the convicts demonstrated their readiness to serve a criminal sentence for religious reasons. They perceived it as divine punishment, and serving the sentence partially removed religious responsibility. Although this state of affairs is inherent only in a certain category of criminals, as a rule, convicted of unintentional crimes, but the majority of convicts $(68.75 \%)$ noted a religious prohibition, and not fear of criminal punishment $(31.25 \%)$, as the main deterrent factor in committing crimes.

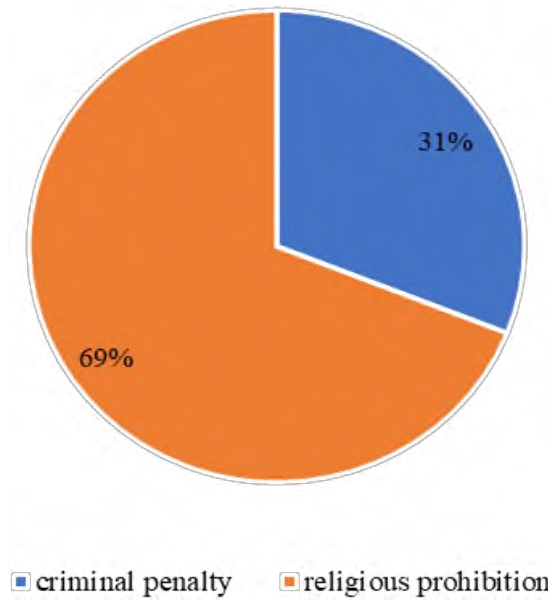

Fig. 1. Factors deterring from committing a crime (based on a comparative analysis of questionnaires of convicted Muslims who are serving a sentence in correctional institutions of Russian Federation).

Legal consciousness and legal culture of various communities have not been adequately studied. The formation of legal identity occurs against the background of rejection of any centralized legal ideology, which subsequently led to a significant variability of types of civil legal consciousness, up to the emergence of formations with a right- or left-radical bias. The current gap in the knowledge of essence of legal consciousness of society leads to a distorted perception of legal reality at the level of both lawmaking and law enforcement, and legal understanding by the population of foundations of current positive law.

\section{Discussion}

It is impossible to talk about an unambiguous approach to such a complex and multifaceted phenomenon as Muslim legal consciousness. Variability of its types is determined by the multiplicity of trends within Islam itself, by the direction of political development of countries of Muslim world. A number of Muslim states have been leading the ratings of safe countries for many years, but it makes no sense, in this regard, to unnecessarily idealize Muslim legal consciousness for the simple reason that many Muslim states close the same rating. Here, not only the factor of religiosity or legal consciousness of citizens is significant, this factor depends on a whole range of conditions and reasons (not always even of a legal nature: economic, political, geographical). 
Nevertheless, the law is a product of legal culture of people, which has absorbed peculiarities of development, formation of statehood, past merits and achievements of indigenous people, as well as historical upholding of values that are reflected in modern law. And in this sense, the values for each culture are individual and represent a centralizing symbol of law.

The level of legal awareness is correlated based on the levels of legal consciousness, there is an objective relationship between the knowledge of law and religious dogma inherent in the doctrinal and professional level of Muslim religious legal consciousness. Perhaps this pattern is formed from the essence of these levels of legal awareness, which have a high legal cognitive potential, which coincides in basic moments with the philosophy of law.

In the doctrinal and professional Muslim legal consciousness, a certain, natural-legal understanding of law is expressed, which presupposes the presence of knowledge about law, but the everyday mass legal consciousness tends more towards cultural or moral legal consciousness, which perceives religion as an element of culture, or fundamentalist Muslim legal consciousness, striving for the sacralization of legal knowledge, have not so high levels of legal awareness. Human mind, from the standpoint of orthodox Islamic law, cannot recognize the true values and standards of behavior. Such knowledge can be acquired only through divine revelation, and actions are right or harmful only because God qualified them so. In the Islamic concept, law precedes and shapes society. The structure of the state and society should ideally correspond to its invariably effective prescriptions.

Ordinary legal consciousness overlaps the entire range of social relations, and therefore out of connection with the main forms of social consciousness, in particular with religious consciousness, in which the regulatory potential is strong enough, it is impossible, nonvital. The lack of persistent religious legal awareness demonstrates another extreme - the lack of relationship between legal knowledge and religious legal awareness deprives the concept of legal awareness of a legal nature - the consciousness of law itself appears to be secondary, devoid of its sacred meaning, the law ceases to reflect its nature, seems torn out of its ideological field and is perceived only as a reflection of the will of the state or the will of the ruling class.

The above brief description of types of Muslim legal consciousness determines the methodology of this study, which will not be reduced to any specific legal approach or direction of legal thought, it is advisable to use the arsenal of all theoretical and legal approaches (natural-legal, positivist, civilizational-historical). The research uses methods of natural-legal, cultural and positive nature. A broader general scientific approach is required, much more effective. The developed legal consciousness of a person reflects the perfect state, the basis of which is formed by the subject of natural law and the will of the individual directed towards it.

The existing diversification of Muslim legal consciousness has determined the high importance of determining the types of Muslim legal consciousness and their essence, taking into account the variability of Muslim legal system and proposed standard classification. At the same time, consideration of religious legal consciousness should be carried out without direct reference to law, legal system and a strictly defined religious trend, since, despite the declared commonality of religious dogmas and requirements, in fact there are several small but significant differences in ideological attitudes towards believers. If such requirements are considered through the prism of interpretation, then the meaning, multidirectionality and variability of religious movements can be simply enormous.

Along with the specific features of Muslim religious sense of justice, which predetermine its division into types, a separate classification is possible, due to the presence of many religious movements in Islam, including radicalized ones. The characteristic of 
modern Muslim legal systems allows us to make their typology based on identifying the diversity of models of perception of positive law by persons professing Islam. In other words, the population of modern Muslim countries demonstrate the types of Muslim legal consciousness and the variability of Islamic legal thinking. As noted above, the factors of this variability are cultural impact on formation of legal system of individual regions and the presence of different approaches to the interpretation of religious and doctrinal sources in Islamic law. Accordingly, the study of types of Muslim legal consciousness can be carried out on the basis of an analysis of legal consciousness or individual legal aspects in specific states, while obtaining various characteristics of Muslim legal consciousness, revealing its various essential characteristics. At the same time, an analysis of legal thinking of Muslims living outside of Muslim legal systems, as well as an analysis of legal practice of radical political entities.

\section{Conclusion}

Summing up, and proceeding from all of the above mentioned, it can be noted that legal consciousness is a regulatory component of a person's legal life and, within the framework of a positive meaning, motivates stability and optimal functioning of legal consciousness in the broad public masses. Moreover, legal consciousness includes not only the impact of a wide range of legal means on social relations, but also the appearance of the result of such an impact. As a result, legal consciousness predetermines the presence of mutual relations in the legal system capable of ensuring the existence of principle of consistency and the basis for its practical implementation.

\section{Acknowledgments}

The author expresses deep gratitude to the leadership of Federal State Institution of Scientific Research Institute of Federal Penitentiary Service of Russia for the help and support provided during this study.

\section{References}

1. M.A. Yunusov, E.A. Yunusov, Modern Law 5, 34-37 (2008)

2. Ya.V. Beznosova, Izvestia of Sochi State University 4-2(33), 86-87 (2014)

3. A.A. Yunusov, S.A. Yunusov, Criminal executive law 3(21), 45-49 (2015)

4. E.A. Yunusov, M.G. Olenev, Bulletin of the public research laboratory "Interaction of the penal system with civil society institutions: historical and legal and theoretical and methodological aspects" 15, 198-201 (2019)

5. A.A. Yunusov, M.A. Yunusov, Politics and Society 1, 79 (2006)

6. A.A. Abdurazakov, History of State and Law 20, 48-52 (2016)

7. M.G. Olenev, Bulletin of the public research laboratory "Interaction of penal system with civil society institutions: historical, legal and theoretical and methodological aspects" 6, 153-157 (2016)

8. E.A. Yunusov, Tourism: law and economy 5, 45-47 (2006)

9. A.A. Abdurazakov, Bulletin of the Academy of the Investigative Committee of Russian Federation 1(11), 29-32 (2017)

10. E.A. Yunusov, A.A. Abdurazakov, Collection: Scientific works of the PKU NII FSIN of Russia. scientific and practical quarterly edition (Moscow, 2020) 
11. E.A. Yunusov, S.M. Vorobiev, A.G. Akhverdyan, A.G. Grunin, R.D. Khritin, Dilemas contemporáneos: Educación, Política y Valores 7(S10), 83 (2019)

12. V.P. Malakhov, S.S. Mayilyan, K.E. Sigalov, Legal science and practice: Bulletin of Nizhny Novgorod Academy of the Ministry of Internal Affairs of Russia 4(40), 26 (2017)

13. I.A. Ilyin, Collected works: In 10 volumes. V. 2. Book. 2 (Russian book, M., 1993)

14. S.A. Yunusov, Man: crime and punishment 3(74), 23-26 (2011)

15. S.A. Yunusov, History of State and Law 10, 24-27 (2014)

16. A.A. Yunusov, M.A. Yunusov, Law and state: theory and practice 3, 24-36 (2006)

17. A.A. Abdurazakov, Lawyer of the South of Russia and Transcaucasia 4(20), 33-36 (2017)

18. V.F. Lapshin, S.A. Korneev, E3S Web of Conferences 135, 04063 (2019) DOI: 10.1051 / e3sconf / 201913504063

19. A.A. Brovkina, V.E. Vezlomtsev, S.S. Zakharova, O.A. Shuranova, Yu.V. Truntsevsky, E3S Web of Conferences 135, 04066 (2019) DOI: 10.1051 / e3sconf / 201913504066 